\title{
COMPARATIVE STUDY OF HUMAN INTESTINAL AND HEPATIC ESTERASES AS RELATED TO ENZYMATIC PROPERTIES AND HYDROLIZING ACTIVITY FOR ESTER-TYPE DRUGS
}

\author{
Michiko INOUE, Masako MORIKAWA, Minoru TSUBOI, \\ Yoshimasa ITO* and Mamoru SUGIURA* \\ Department of Pharmacology, Tokyo College of Pharmacy, \\ Hachioji, Tokyo 192-03, Japan and *Department of Pharmacy, \\ Gifu College of Pharmacy, Gifu 502, Japan
}

Accepted February 21, 1980

\begin{abstract}
In attempts to determine the exact role of intestinal esterase in the body, we purified esterases from human intestinal mucosa and liver, and compared the enzymatic properties and substrate specificities with those of purified esterases. Esterase from human liver was purified 58-fold, by treatment with butanol, DE-52 and DEAE Sephadex A-50 column chromatographies, Sephadex G-200 gel filtration, and isoelectric focusing. The purified preparation showed a single band by polyacylamide gel electrophoresis. The molecular weights of intestinal and hepatic esterases were determined to be $53,000-55,000$ and 180,000 , respectively, by gel filtration on Sephadex G-200. The activity of the purified intestinal and hepatic esterases was strongly inhibited by diethyl-p-nitrophenyl phosphate and diisopropyl fluorophosphate, and was not inhibited by eserine sulfate and p-chloromercuribenzoate. Moreover, the purified esterases hydrolyzed ester-type drugs such as aspirin, clofibrate, indanyl carbenicillin and procaine. Hepatic esterase had properties similar to those of intestinal esterase with respect to the sensitivity to organophosphate and the substrate specificity. However, the two purified esterases differed in properties such as molecular weight, isoelectric point, thermostability and optimal $\mathrm{pH}$.
\end{abstract}

Carboxylesterase capable of hydrolyzing carboxyl esters, thiol esters and armatic amides, is found in most animal tissues (1).

Recently a variety of ester-type drugs are being used in various ways as prodrugs (2). Ester-type prodrugs are hydrolyzed by esterases in intestinal mucosa, liver and serum, and the degree of hydrolysis affects their pharmacological activities. There are, however, only a few reports on the purification and properties of human intestinal esterase and hepatic esterase (3). We have already reported the purification of esterase from human intestinal mucosa $(4,5)$. When esterase from intestinal mucosa has been examined for its action in the metabolism of ester-type drugs in the body, esterase from liver must also be considered.

In this paper, we detailed the difference of two esterases in their enzymatic properties and substrate specificities.

\section{MATERIALS AND METHODS}

Enzyme purification: The small intestine (jejunum) and liver were obtained from humans at the time autopsy carried out $12 \mathrm{hr}$ after death. Esterase from the intestinal 
mucosa was purified according to the method described in our previous paper (5).

The crude enzyme was obtained from the liver as reported previously (6). The liver was homogenized in 4 volumes of cold water-butanol solution $(1: 3, v / v)$, the homogenate was centrifuged at $12,000 \mathrm{rpm}$ for $20 \mathrm{~min}$, and the aqueous layer containing esterase was collected. The crude enzyme solution was subjected to fractional precipitation by ammonium sulfate. The precipitate obtained at $0.4-0.5$ saturation was collected and dialyzed against 1 liters of $10 \mathrm{mM}$ Tris- $\mathrm{HCl}$ buffer $\left(\mathrm{pH} \mathrm{7.4)}\right.$ for $24 \mathrm{hr}$ at $4{ }^{\circ} \mathrm{C}$. The dialyzed solution was applied to a DE-52 column equilibrated with $10 \mathrm{mM}$ Tris- $\mathrm{HCl}$ buffer ( $\mathrm{pH}$ 7.4). The enzyme was eluted with a linear gradient of $\mathrm{NaCl}$ concentration from 0 to $0.3 \mathrm{M}$. The enzyme solution was collected and concentrated using membrane filter, then subjected to gel filtration on a Sephadex G-200 column. The esterase solution was collected and dialyzed against $10 \mathrm{mM}$ Tris- $\mathrm{HCl}$ buffer ( $\mathrm{pH} \mathrm{7.4)}$ for $24 \mathrm{hr}$. The dialyzed solution applied to a column of DEAE Sephadex A-50 and the enzyme was eluted with a linear gradient of $\mathrm{NaCl}$ concentration from 0 to $0.3 \mathrm{M}$. The enzyme solution from the DEAE Sephadex A-50 was concentrated, and dialyzed overnight against $10 \mathrm{mM}$ Tris- $\mathrm{HCl}$ buffer, $\mathrm{pH}$ 7.4. The solution was then subjected to isoelectric focusing.

Assay of esterase activity: The activities of esterase and lipase were determined according to our methods described previously, using $\beta$-naphthyl derivatives, phenyl acetate, tributyrin and olive oil as substrates $(7,8)$. The drug-hydrolyzing activity was also determined according to our method, using acethylsalicylic acid (aspirin), salicylic acid derivatives, ethylchlorophenoxy-isobutyrate (clofibrate, CPIB), indanyl carbenicillin (I-CBPC), procaine, atropine, acethylcholine, benzylcholine and procainamide as substrates $(4,9)$.

Assay of protein: The protein content was determined according to the method of Lowry et al. (10) or U.V. absorbance at $280 \mathrm{~nm}$.

Disc electrophoresis: Disc electrophoresis was carried out according to the method of Davis (11) using $7.5 \%$ polyacrylamide gel at $\mathrm{pH} 9.4$.

Isoelectric focusing: Isoelectric focusing was done according to the method of Vesterberg and Sevensson (12) using $1 \%$ carrier ampholyte, $\mathrm{pH} 4.0-6.0$. After the electrophoresis, the esterase activity, $\mathrm{pH}$ and protein content of the eluate from column were determined.

Synthesis of salicylic acid esters: Aspirin was obtained commercially. Four other salicylic acid esters, with 3 to $6 \mathrm{C}$ atoms, were prepared from acid anhydrides. The longchain compounds $\left(\mathrm{C}_{7}, \mathrm{C}_{8}\right)$ were prepared from the corresponding acid chlorides by a procedure similar to that already reported $(13,14)$.

\section{RESULTS}

Purification of esterase from human intestinal mucosa and liver: At each step of purification, the yield and specific activity of esterase are summarized in Tables 1 and 2 .

Using $\beta$-naphtyl acetate as a substrate, the specific activity of purified intestinal esterase was increased aprox. 210-fold over that of the initial crude enzyme preparation with recovery of $8.5 \%$. The purified preparation showed a single band by disc electrophoresis. The hepatic esterase was purified about 58.0-fold over that of the crude enzyme with recovery 
TABLE 1. Purification of esterase from human intestinal mucosa

\begin{tabular}{lccccc}
\hline \multicolumn{1}{c}{ Fraction } & $\begin{array}{c}\text { Total protein } \\
\text { (mg) }\end{array}$ & $\begin{array}{c}\text { Total activity } \\
\text { (units)* }\end{array}$ & $\begin{array}{c}\text { Specific activity } \\
\text { (units/mg) }\end{array}$ & Fold & $\begin{array}{c}\text { Yield } \\
(\%)\end{array}$ \\
\hline Crude enzyme & 551.6 & 1239.0 & 2.2 & 1 & 100.0 \\
Supernatant** & 151.9 & 1180.0 & 7.8 & 4 & 95.2 \\
DEAE-Cellulose & 26.78 & 592.5 & 22.1 & 10 & 47.8 \\
Sephadex G-100 & 6.33 & 310.2 & 49.0 & 22 & 25.0 \\
Hydroxyapatite & 1.55 & 214.5 & 138.4 & 63 & 17.3 \\
Isoelectric focusing & $0225^{* * *}$ & 105.6 & 469.3 & 213 & 8.5 \\
\hline
\end{tabular}

Esterase activities were measured using $\beta$-naphthyl acetate as substrate. *units: $\mu$ moles/min. $\quad{ }^{* *}$ Homogenate solution treated by Triton X-100. ***Protein estimated by absorbance at $280 \mathrm{~nm}$.

TABLE 2. Purification of esterase from human liver

\begin{tabular}{lccccc}
\hline \multicolumn{1}{c}{ Fraction } & $\begin{array}{c}\text { Total protein } \\
\text { (mg) }\end{array}$ & $\begin{array}{c}\text { Total activity } \\
\text { (units)* }\end{array}$ & $\begin{array}{c}\text { Specific activity } \\
\text { (units/mg) }\end{array}$ & Fold & $\begin{array}{c}\text { Yield } \\
(\%)\end{array}$ \\
\hline Crude enzyme & 2151 & 3751 & 1.74 & 1.0 & 100.0 \\
Ammonium sulfate** & 600 & 2338 & 3.90 & 2.2 & 62.3 \\
DE-52 & 190 & 1080 & 5.68 & 3.3 & 28.8 \\
Sephadex G-200 & 57.1 & 800 & 14.0 & 8.0 & 21.3 \\
DEAE-Sephadex A-50 & 18.4 & 416 & 22.1 & 12.7 & 11.1 \\
Isoelectric focusing & 42 & 426 & 101.0 & 58.0 & 11.4 \\
\hline
\end{tabular}

Esterase activities were measured using $\beta$-naphthyl acetate as substrate. *units; $\mu \mathrm{moles} / \mathrm{min}$. **Ammonium sulfate fractionation: 0.40 .5 saturation.
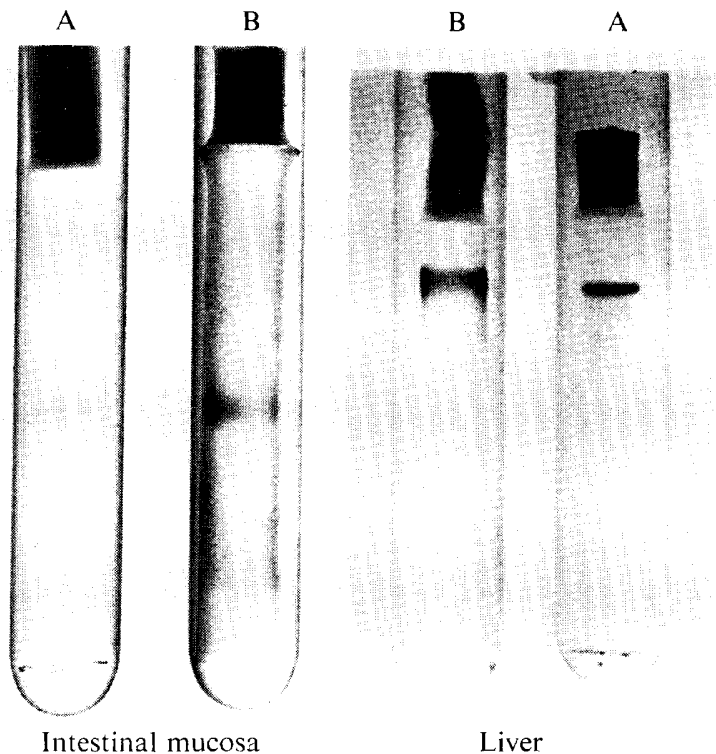

FIG. 1. Disc electrophoresis of the esterase purified from human intestinal mucosa and liver. Electrophresis was carried out at a constant current of $3 \mathrm{~mA} /$ column for 90 min using $7.5 \%$ polyacrylamide gel ( $\mathrm{pH} 9.4)$. After electrophresis, protein (A) and esterase (B) were stained with amidoblack $10 \mathrm{~B}$ and Fast blue B, respectively. 
of purified enzyme and it gave a single band after disc electrophoresis at pH 9.4 (Fig. 1).

Effect of various agents on hepatic and intestinal esterases: Various agents were examined for their effects on the purified intestinal and hepatic esterases. As shown in Table 3 , both esterase activities were strongly inhibited by diethyl p-nitrophenyl phosphate (E-600) and diisopropyl fluorophosphate (DFP), however, eserine sulfate and p-chloromercuribenzoate (PCMB) had no effect.

Substrate specificities of hepatic and intestinal esterases: The substrate specificities of purified intestinal and hepatic esterases are summarized in Table 4. Among the $\beta$ naphthyl esters tested, two esterases showed the highest hydrolytic activity to $\beta$-naphthyl butyrate. These purified esterases hydrolyzed ester-type drugs such as aspirin, clofibrate, indanyl carbenicillin and procaine, but did not hydrolyze olive oil, $\beta$-naphthyl olate, amidetype drugs such as procainamide and three cholines.

The esterase activity measured in the presence of the esters synthesized from salicylic acid as substrates is shown in Fig. 2. These esterase activities are shown as the relative ratio to the hydrolyzed amount of aspirin and hydrolyzed acylsalicylic acid derivatives more rapidly than they did carboxylphenyl carbonate derivatives. Intestinal esterase rapidly hydrolyzed propionyl salicylic acid and $n$-heptanoyl salicylic acid than other acylsalicylic acid esters. The activity pattern of hepatic esterase differed from that of the intestinal esterase. The hydrolysis rate of hepatic esterase was influenced by the number of $\mathrm{C}$ atoms in those ester moieties of the substrates. Among all the synthesized esters, $n$-octanoylsalicylic acid was the most rapidly hydrolyzed.

Enzymatic properties of hepatic and intestinal esterases: The molecular weights were estimated according to the method of Whittaker (15), by gel filtration on Sephadex G-200. The molecular weights of intestinal and hepatic esterases were calculated to be $53,000-$

TABLE 3. Effect of various agents on activity of purified esterase from human intestinal mucosa and liver

\begin{tabular}{lcc}
\hline & $\begin{array}{c}\text { Intestinal mucosa } \\
\text { remaining activity }\end{array}$ & $\begin{array}{c}\text { Liver } \\
(\%)\end{array}$ \\
\hline None & 100 & 100 \\
O-Phenanthroline & 84.0 & 84.1 \\
EDTA & 85.8 & 108.0 \\
Monoiodoacetate & 94.8 & 87.3 \\
N-Bromosuccinimide & 99.0 & 61.8 \\
L-Cysteine & 58.9 & 73.3 \\
2-Mercaptoethanol & 44.8 & 101.0 \\
Jodine & 47.0 & 82.9 \\
p-Chloromercuribenzoate & 97.8 & 98.2 \\
Eserine sulfate & 101.0 & 100.0 \\
Diethyl p-nitrophenyl phosphate* & N.D. & N.D. \\
Diisopropyl fluorophosphate* & N.D. & N.D. \\
\hline
\end{tabular}

Esterase activities were determined using $\beta$-naphthyl acetate as substrate after treatment with $50 \mathrm{mM}$ Tris- $\mathrm{HCl}$ buffer $(\mathrm{pH} 7.5)$ at $37 \mathrm{C}$ for $30 \mathrm{~min}$. *The concentration of agents was $10^{-4} \mathrm{M}$ except for $10^{-6 *}$. N.D.; Not detectable. 
TABLE 4. Substrate specificity of purified esterase from human intestinal mucosa and liver

\begin{tabular}{lccc}
\hline Substrate & $\begin{array}{c}\text { Concn.* } \\
(\mathrm{mM})\end{array}$ & $\begin{array}{c}\text { Intestinal mucosa } \\
\text { Relative activity** }\end{array}$ \\
\cline { 3 - 4 }$\beta$-Naphthyl acetate & 0.2 & 100 & 100 \\
$\beta$-Naphthyl propionate & 0.2 & 311 & 479 \\
$\beta$-Naphthyl butyrate & 0.2 & 354 & 1196 \\
$\beta$-Naphthyl valerate & 0.2 & 291 & 89 \\
$\beta$-Naphthyl caprate & 0.2 & 23 & 86 \\
$\beta$-Naphthyl oleate & 0.2 & N.D. & N.D. \\
Olive oil & $(10 \%)$ & N.D. & N.D. \\
Phenyl acetate & 3.0 & 102 & 96 \\
Aspirin & 5.0 & 1.01 & 0.74 \\
Indanyl carbenicillin & 0.5 & 0.37 & 1.10 \\
Clofibrate & 1.6 & 0.39 & 0.14 \\
Procaine & 2.0 & 0.48 & 0.34 \\
Atropine & 2.0 & N.D. & 0.38 \\
Acetylcholine & 2.0 & N.D. & N.D. \\
Benzoylcholine & 2.0 & N.D. & N.D. \\
Procainamide & 2.0 & N.D. & N.D. \\
\hline
\end{tabular}

*Substrate concentration. ${ }^{* *}$ Rate of hydrolysis was expressed as the ratio relative to the hydrolyzed amount $\beta$-naphthylacetate. N.D.; Not detectable.

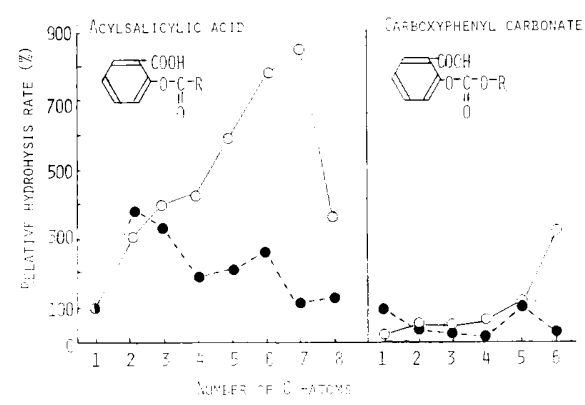

FIG. 2. Relative rate of hydrolysis of esterase with respect to esters of acylsalicylic acid and carboxyphenyl carbonate of different carbon chain length.

- Intestinal esterase, $-\mathrm{O}-$ Hepatic esterase

55,000 and 180,000 , respectively. When subjected to gel electrophoresis in the presence of $0.1 \%$ SDS (3), hepatic esterase showed one main band. From the calibration curve, the subunit weight of the main enzyme band was estimated to be 61,000 . The isoelectric points of intestinal and hepatic esterases were estimated to be pI 5.02 and pI 5.92, respectively. Intestinal esterase had the optimum $\mathrm{pH}$ of $7.5-8.0$ for the enzyme activity in the standard assay system while hepatic esterase had the optimum $\mathrm{pH}$ of 6.5. The stability of these esterases was also examined under conditions of various $\mathrm{pH}$ and temperatures. Intestinal esterase was stable in the $\mathrm{pH}$ range of $6.5-9.0$, and also stable below $40^{\circ} \mathrm{C}$, when the 
TABle 5. Properties of purified esterase from human intestinal mucosa and liver

\begin{tabular}{lll}
\hline & Intestinal mucosa & Liver \\
\hline Molecular weight & & 180,000 \\
$\quad$ Sephadex G-200 & $53,000-55,000$ & 61,000 \\
$\quad$ SDS-polyacrylamide & & 5.92 \\
Isoelectric point (pI) & 5.02 & 6.5 \\
Optimal pH & $7.5-8.0$ & $\mathrm{pH} 6.5-7.5$ \\
Stablility* & $\mathrm{pH} 6.5-9.0$ & $50^{\circ} \mathrm{C}, 45$ min \\
& $40^{\circ} \mathrm{C}, 45$ min & DFP, E-600 \\
Inhibitors & DFP, E-600 & $\beta$-naphthyl esters \\
Substrate & $\beta$-naphthyl esters & Ester-type drugs \\
& Ester-type drugs &
\end{tabular}

${ }^{*}$ Enzyme activities were determined at various $\mathrm{pHs}$ and temperatures. The $\mathrm{pH}$ and thermal stability are expressed as $90 \%$ of the remaining activity compared to the control value.

solution was incubated for $45 \mathrm{~min}$. Hepatic esterase was stable in the $\mathrm{pH}$ range of 6.5-7.5, and also stable below $50^{\circ} \mathrm{C}$, when the solution was incubated for $45 \mathrm{~min}$.

\section{DISCUSSION}

Carboxylesterases present in various tissues play an important role in the metabolism of ester-type drugs $(4,7)$.

We purified esterases from human intestinal mucosa and liver and examined enzymatic properties and substrate specificity. Two esterases hydrolyzed $\beta$-naphthyl esters and ester-type drugs such as aspirin, salicylic acid derivatives, clofibrate, indanyl carbenicillin and procaine. The substrate specificity of hepatic esterase was similar to that of intestinal esterase. The two esterases were found to belong to carboxylesterase (B-esterase), as they were inhibited by organophosphates such as DFP and E-600 (1). The molecular weight of hepatic esterase was about 180,000 as estimated by Sephadex G-200 gel chromatography. For the molecular weight of subunit, a value of 61,000 was obtained by SDS-polyacrylamide gel electrophoresis. This is not in good agreement with the findings of Junge et al. (3) who estimated the molecular weight of human hepatic esterase to be in the range of 181,000 186,000 and composed of three subunits of equal size. On the other hand, the molecular weight of intestinal esterase was 53,000-55,000 and less than that of hepatic esterase.

These results suggest that hepatic esterase has properties similar to those seen with intestinal esterase, that is substrate specificity and the reaction to organophosphate. However, it does differ in molecular weight, isoelectric point, thermostability and optimal $\mathrm{pH}$. Intestinal esterase is more stable than hepatic esterase. The specific activity of intestinal esterase using aspirin as a substrate was three times higher than that of hepatic esterase (data not shown). 


\section{REFERENCES}

1) Krisch, K.: Carboxylic ester hydrolase. The enzyme, Edited by Boyer, P.O., Vol. V, p. 4385, Third edition, Academic Press, New York and London (1971)

2) Sinlula, A.A. and Yalkowky, S.H.: Rationale for design of biologically reversible drug derivatives; Prodrugs. J. Pharm. Sci. 64, 181-210 (1975)

3) Junge, W., Heymane, E. and Krisch, K.: Human liver carboxylesterase; Purification and molecular properties. Arch. Biochem. Biophys. 165, 749-763 (1974)

4) Inoue, M., Morikawa, M., Tsuboi, M. and Sugiura, M.: Species difference and characterization of intestinal esterase on the hydrolyzing activity of ester-type drugs. Japan $J$. Pharmacol. 29, 9-16 (1979)

5) Inoue, M., Morikawa, M., Tsuboi, M., Yamada, T. and Sugiura, M.: Hydrolysis of ester-type drugs by the purified esterase from human intestinal mucosa. Japan $J$. Pharmacol. 29, 17-25 (1979)

6) Sugiura, M., Isobe, M., Hirano, K., Iino, S., Suzuki, H. and Oda, T.: Purification of human intestinal alkaline phosphatase. Chem. Pharm. Bull. 23, 1537-1541 (1975)

7) Morikawa, M., Inoue, M. and Tsubor, M.: Substrate specificity of carboxylesterase from several animals. Chem. Pharm. Bull. 24, 1661-1664 (1976)

8) Sugiura, M., Isobe, M., Oikawa, T. and Oono, H.: Sterol ester hydrolytic activity of Lipoprotein lipase from pseudomonas fluorescence. Chem. Pharm. Bull. 24, 1202-1208 (1976)

9) Inoue, M., Morikawa, M., Tsuboi, M. and Sugiura, M.: Studies of human intestinal esterase IV. Application to the development of ester prodrugs of salicylic acid. $J$. Pharm. Dyn. 2, 229-236 (1979)

10) Lowry, O.H., Rosebrough, N.J., Farr, A.L. and Randall, R.J.: Protein measurement with the Folin phenol reagent. J. biol. Chem. 193, 265-275 (1951)

11) Davis, B.J.: Disc electrophoresis, II. Method and application to human serum protein. Ann. N. Y. Acad. Sci. 121, 404-427 (1964)

12) Vesterberg, O. and Sevensson, H.: Isoelectric fractionation, Analysis and characterization of ampholytes in natural pH gradient. Acta chem. Scand. 20, 820-834 (1966)

13) Hofstee, B.H.: Specificity of esterase. J. biol. Chem. 199, 357-364 (1952)

14) Differt, L.W., Caldwell, H.C., Ellison, T., Irwin, A.W., Rivard, D.E. and Swintosky, J.V.: Carbonate ester prodrugs of salicylic acid. J. Pharm. Sci. 57, 828-831 (1968)

15) Whittaker, J.R.: Determination of molecular weight of proteins. Analyt. Chem. 35, 19501953 (1963) 